\title{
DEVELOPING CONCEPTUAL GOVERNANCE MODEL FOR COLLABORATIVE KNOWLEDGE MANAGEMENT SYSTEM IN PUBLIC SECTOR ORGANISATIONS
}

\author{
${ }^{1}$ Azlina Ali, ${ }^{2}$ Rozi Nor Haizan Nor, ${ }^{3}$ Rusli Abdullah \& \\ ${ }^{4}$ Masrah Azrifah Azmi Murad \\ Universiti Putra Malaysia, Malaysia
}

\begin{abstract}
imiazlina@yahoo.com; rozinor@upm.edu.my; rusli@upm.edu.my; masrah@upm.edu.my
\end{abstract}

\begin{abstract}
Nowadays most of the public sector organisations are implementing a knowledge management system (KMS) to assist the systematic creation and sharing of their knowledge resources. The recent technological needs, collaboration and cooperation among public sector organisations (PSO) serve a vital role in the development of knowledge management systems (KMS). However, in order to establish a successful and standardised collaborative KMS amongst Malaysian PSO (MPSO), proper governance needs to be in place. The aim of this study is to identify governance components for collaborative KMS (CKMS). Accordingly, the journal articles published within the period 1998-2013 were identified and analysed. The articles were sourced mainly from Knowledge Management Research \& Practice, Science Direct, Emerald, MIS Quarterly, as well as from some other academic databases. Keywords used during the literature search were "governance", "knowledge management system", "collaboration", "collaborative knowledge management system", "knowledge sharing" and "knowledge management governance". Moreover, expert opinion from the public sector expert teams and academic experts was also acquired from several consultation sessions to ensure that the components obtained from the readings meet the requirements of KMS collaborations. Based on the analysis and consultation, a conceptual model for governance of CKMS is constructed.
\end{abstract}

Keywords: governance, knowledge management system, collaborative knowledge management system. 


\section{INTRODUCTION}

Information and communication technology (ICT) has changed the landscape of organisation business basis. Day-by-day, ICT and its costs are starting to be an essential part of an organisation's need. Furthermore, with the recognition of knowledge as an asset, the role of ICT has been increased to enable capitalisation of information and knowledge by supporting KM processes of creation, sharing, application and transfer of knowledge. Thus, leveraging ICT successfully has become the business competency, and is critical for the survival and success of business.

The management of information technology (IT) comes under the IT governance authority and has become a topic of research interest. IT governance is defined as the decision rights and accountability framework to encourage the desirable behaviour in the use of IT (Weill \& Ross, 2004). Researches have shown that the organisation with proper IT governance will achieve at least 20 percent higher returns on assets, more than organisations with weaker governance (Weill, 2004). Furthermore, better governance of IT lead to improved IT outcomes (IT Governance Institute, 2009).

KM governance is a detachment of IT governance (Grundstein, 2006). Previous research has acknowledged KM governance as the structuring of the KM function, the distribution of KM decision-making rights and responsibilities among enterprise stakeholders, as well as the structures and processes for making and monitoring strategic decisions regarding $\mathrm{KM}$ (Schroeder \& Pauleen, 2007). The role of KM governance is to provide the policies, processes and procedures necessary to ensure that the program works effectively. These must be clearly communicated to everyone involved. Governance covers the integrated management of the program from its initial development, through production running until its end-of-life close down. A research focusing on KM governance could provide important insights into how KM programs can be better established and run in organisations.

In the Malaysian context, the efficiency and effectiveness of public sector organisations (PSO) has been a significant concern (Ali, 2003). According to the Malaysian Public Complaints Bureau, most of the complaints received from 2009 to July 2013 were about failures or delays in attending or responding to the needs of customers (BPA, 2012). This is partly due to the lack of information and collaboration between government agencies (Ninth Malaysia Plan, 2006). 
The application of KM in Malaysian public sector organisations (MPSO) is not fully optimised due to a lack of sharing culture and different understandings of its concept (MAMPU, 2011a). Knowledge management systems (KMS) within MPSO mostly operate and work in silos or within the organisation. MPSO also decline in sharing the knowledge gained due to ownership of data or knowledge (MAMPU, 2011a). This lack of collaboration can contribute to the denial of knowledge sharing and dissemination (MAMPU, 2011a; Mohd Nor et al., 2009).

Therefore, in order to ensure the success and standardisation of collaborative KMS amongst MPSO, proper governance needs to be in place. MPSO can improve productivity through a consolidation and collaboration exercise, which will result in increased productivity, minimised redundancies and improved efficiencies through the centralised management and maintenance of shared resources (Abdullah et al., 2005; Tenth Malaysian Plan, 2011).

This study focuses on the collaborative knowledge management system (CKMS) components and governance, established from a review of literature by the researchers and expert opinion acquired from several consultation sessions. The remainder of this paper is structured as follows. The next section provides a brief review of literature related to KMS, CKMS and the governance of KMS. This is followed by a discussion on the current KMS environment in MPSO, its barriers and adoption of CKMS within MPSO. Then the preliminary findings on the governance components of CKMS and proposed conceptual framework are presented. Furthermore, the paper also discusses the measurement factors that can be considered further in implementing or using the conceptual framework. The final section concludes the study.

\section{RELATED RESEARCH}

This section provides a brief background on KMS and CKMS, which is then followed by an overview of governance of KMS.

\section{Knowledge Management Systems}

Knowledge is defined as the expertise and skills acquired by a person through experience or education. It is derived from information and context through learning and judgement. Davenport defined KM as the process of capturing, distributing and effectively using knowledge (Davenport, 1994). 
Organisational knowledge is an organisational asset covering the knowledge of an organisation's employees and group knowledge embedded in the organisational policies, procedures and protocols ( $\mathrm{Wu} \& \mathrm{Gu}, 2009)$. The Gartner Group (1996) promotes KM as an integrated approach to identifying, capturing, evaluating, retrieving and sharing all of an organisation's knowledge assets (Gartner Group Inc, 1996). These assets may include databases, documents, policies, procedures and previously unrecorded expertise and experience in individual workers.

KM plays an important role in transforming tacit knowledge (personal ideas and experiences) from individual knowledge to explicit organisational knowledge (documents, products and procedures) and utilising shared knowledge effectively across an organisation (Davenport \& Prusak, 1998; Nonaka \& Takeuchi, 1995) through various functions by personal, mechanical and electronic means (Hernandez, 2003).

Furthermore, a KMS is an information system designed to increase the utilisation and the creation of knowledge with the aim to improve organisation's effectiveness. From the technical perspective, KMS as information systems are designed specifically for identifying, understanding, capturing, sharing, disseminating, retrieving, integrating and leveraging knowledge (Abdullah et al., 2005; Alavi \& Leidner, 1999). KMS are designed, developed and deployed to assist organisations to manage their knowledge in order to perform tasks and as a decision-making tool for top organisation management (Davenport \& Prusak, 1998). KMS technology has become renowned as an enabling and leading factor for connecting people or working collaboratively and converting data into knowledge (Abdullah \& Misran, 2010).

\section{Collaborative Knowledge Management Systems}

CKMS technology refers to organisational KMS deployment across organisational boundaries (Abdullah et al., 2006; Wu \& Gu, 2009) as shown in Figure 1. The purpose of CKMS is to facilitate intra and inter-organisational KM systematically, in order to create and leverage knowledge resources as well as intellectual assets collaboratively with the goal to improve the overall organisational performance (Abdullah et al.,2007; Cormican \& O’Sullivan, 2003).

In a collaborative environment, sharing is essential to ensure each organisation has the required information in performing the organisation tasks (Mohd Nor et al., 2009). Sharing also enables reputable knowledge and 
prevents organisations from working in silos. Sharing involves organisation infrastructure, organisational learning, shared expertise, organisation's strategic management and organisation integration (Abdullah et al., 2005). The flow of knowledge within the community of practise should be emphasised to ensure more effective organisational social network through knowledge sharing (Różewski et al.,2015).

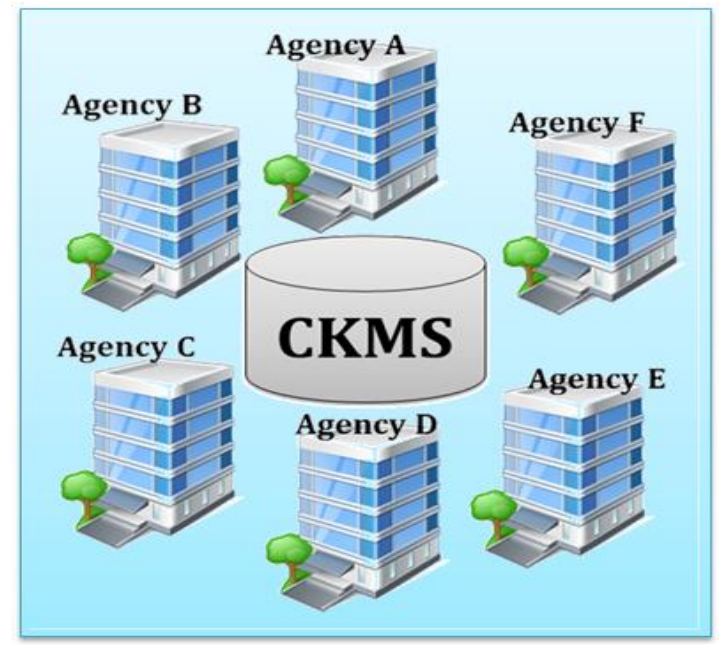

Figure 1. Collaborative KMS.

Previous research has identified major elements of KMS networks that interact and work together as a CKMS (Oyefolahan et al., 2012; Sajeva, 2011). These major elements, as adapted from (Sajeva, 2011) are:

(a) KM process - KM-related activities (identify, acquire, create, store, disseminate and apply knowledge) (Abdullah et al., 2005, Grundstein et al., 2008; Sajeva, 2011);

(b) Strategic management-Management support and promotion (Abdullah et al., 2005, Grundstein et al., 2008; Sajeva, 2011; Salleh, 2012; Moshari, 2013).

(c) Organisational infrastructure - Organisational social networks to ensure the smooth flow of knowledge in an organisation (Abdullah et al., 2005, Grundstein et al., 2008; Sajeva, 2011; Moshari, 2013).

(d) Technological infrastructure - Facilitating the process of $\mathrm{KM}$ systematically with the use of information and communication technologies (Abdullah et al., 2005, Grundstein et al., 2008; Oyefolahan et al., 2012; Sajeva, 2011; Salleh, 2012; Moshari, 2013). 
(e) Organisational learning - Collaborative learning processes amongst organisation personnel (peers and experts) to facilitate knowledge creation and enhancement (Abdullah et al., 2005, Grundstein et al., 2008; Oyefolahan et al., 2012; Sajeva, 2011; Moshari, 2013)

(f) Knowledge culture - Acceptance of the importance of knowledge and KM by the organisational personnel (Oyefolahan et al., 2012; Salleh 2012; Moshari, 2013).

$\mathrm{KM}$ is not simply a system or technology concern. It is an important part of organisational learning. It includes people, processes, techniques, infrastructures and methods in managing knowledge assets. KM requires implementing knowledge initiatives across the entire organisation and should be governed wisely.

\section{Governance of Knowledge Management System}

In the definition of IT governance provided by Grembergen (2004) and Peterson (2004), the KM governance is part of IT governance (Schroeder \& Pauleen, 2007) and is being described as the structuring of the KM functions, the distribution of $\mathrm{KM}$ decision-making rights, responsibilities among enterprise stakeholders as well as the structures and processes for making and monitoring strategic decisions regarding KM".

Best practices in IT governance frameworks such as the Control Objectives for Information and Related Technology (COBIT) and IT Infrastructure Library (ITIL) are often adopted and implemented according to the needs of the organisation. COBIT, for example, consists of 34 objectives and it is categorised into four domains: (a) planning and organisation; (b) acquisition and implementation; (c) delivery and support, and (d) monitoring and evaluation (Abu-Musa, 2009). ITIL is comprised of several areas of service management: service strategy, service design, service transition, service operation and continual service improvement (Winniford et al., 2009). IT governance components consist of an organisation's structure, policy, quality culture, delivery, resource management, finance management, and outsource management (Nor, 2013). Organisational KM initiatives need to be incorporated and distinguished through governance such as structures, processes or relational mechanisms (Schroeder et al., 2012) that would enable employees to execute their responsibilities (Grembergen \& Haes, 2009). Governance is a dynamic process involving implementation and monitoring as well as decision-making (Fazekas \& Burns, 2012). 
KMS governance describes organisational guidelines on managing activities related to knowledge (Cao \& Xiang, 2012). Also, KMS governance is a discipline in "implementing authority through transparent activity to leverage the sum of the knowledge of the organization to fulfil of the aims and objectives of organization" (Zyngier \& Owen, 2013). Thus, in order to ensure success of KMS implementation in organisations, each aspect of the knowledge lifecycle from creation to its being shared across the organisation should be governed and monitored closely by organisation's top management. Proper governance of organisation KMS will contribute in increasing organisation's productivity and quality, as well as indirectly will give a return on investment for the organisation in implementing KMS (Abdullah et al., 2005).

\section{ENVIRONMENT OF KNOWLEDGE MANAGEMENT SYSTEMS IN MALAYSIAN PUBLIC SECTOR ORGANISATIONS (MPSO)}

According to Public Sector Information Architecture Blueprint from MAMPU (MAMPU, 2011a), MPSO are structured with reference to their functions on core sectors (economic, social, security) and supporting sectors (general administration) as shown in Figure 2.

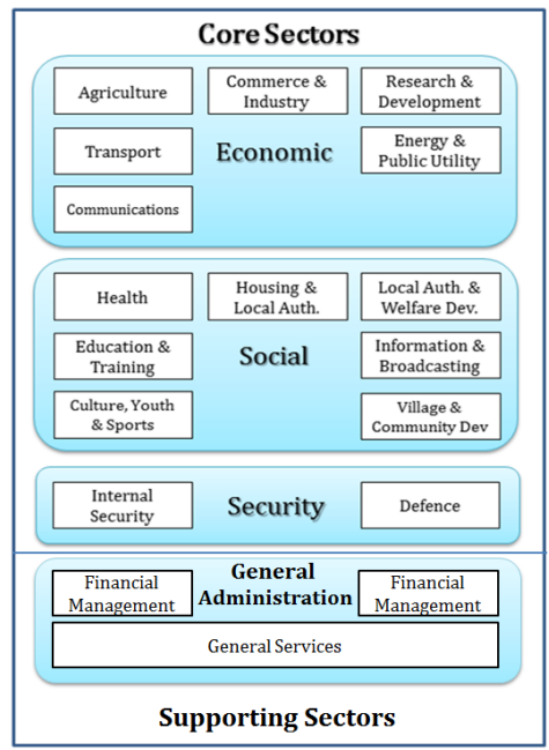

Figure 2. Public Sector Business Model (Core Sectors) MAMPU Information Architecture Blueprint (2011). 
Each sector consists of several ministries and agencies. The economic sector collectively contains several ministries under the portfolio of agriculture, transport, communications, energy, public utility and etc. Respectively each sector represents the information that can be shared collaboratively. MPSO have started in developing their KMS and gradually become knowledge-based organisations since knowledge is their most vital asset (Sandhu et al., 2011). Nevertheless, KMS was found to score low in most agencies (MAMPU, 2011a). This indicated that agencies need to communicate the importance and benefits of KMS whilst setting key definitions, guidelines and boundaries of knowledge within the agencies in order to raise awareness and get the buy-in of personnel.

MPSO work collectively and are still depending on feedback received from other agencies, which can cause delays in the action taken. According to the Public Complaints Bureau of Malaysia, from 2009 until July 2013, on average, 50 per cent of the complaints received were related to failures or delays in attending or responding to the needs of customers (BPA, 2012). Such failures and delays are caused by many factors. One of the factors that has been identified is the lack of information and collaboration between government agencies (Ninth Malaysia Plan, 2006). Other factors that cause failures and delay are knowledge ownership. MPSO are usually not willing to share the knowledge they obtained (MAMPU, 2011a). Findings from a survey of 94 government agencies and from interviews conducted on 30 selected government agencies have shown that KMS in MPSO are not fully optimised due to the lack of a sharing culture and different understandings of its concept (MAMPU, 2011a). Implementation of CKMS initiatives in MPSO would encourage knowledge sharing culture, aid resource allocation based on knowledge portfolio and assist in decision making.

As mentioned, KMS governance is a part of IT governance (Schroeder \& Pauleen, 2007). KMS governance consists of leadership and organisational structures and processes which ensure that the organisation's KMS extends the organisation's strategies and objectives (IT Governance Institute, 2009). Further, KMS governance is defined as the management process, which ensures delivery of the expected benefits of IT in a controlled way to enhance the long-term success of the organisation. CKMS governance tend to build a framework in order to achieve a successful CKMS amongst MPSO and can be promoted as a reference model for CKMS implementation in their organisations. 


\section{Barriers in Knowledge Management Initiatives}

Previous studies (Brown \& Grant, 2005; Chua \& Lam, 2005; Moshari, 2013; Riege, 2005; Schroeder et al., 2012) have depicted a number of scenarios of KM initiatives in MPSO: (a) KMS exist in silos; (b) among agencies, there are different understandings of the KM concept; (c) there is minimal knowledge sharing across the public sector; (d) insufficient work transition plans are developed with regard to knowledge; and (e) agency staff believes that their knowledge solely belongs to their agency.

The researchers have found that the failure of KM programs or initiatives can often be attributed to lack of clear strategic objectives (Chua \& Lam, 2005; Riege, 2005; Schroeder et al., 2012; Moshari, 2013), lack of senior management supervision (Brown \& Grant, 2005; Schroeder et al., 2012), lack of business integration and alignment (Chua \& Lam, 2005; Riege, 2005; Schroeder et al., 2012; Moshari, 2013), and unclear distribution of KM-related authority (Brown \& Grant, 2005; Chua \& Lam, 2005).

Barriers in collaborative KM, which are also barriers in IT governance implementation have been classified into three main categories (Riege, 2005):

(a) Human barriers refer to personal barriers such as communication skills, social networks, recognition, trust, and awareness of the benefits of knowledge collaboration (Jain \& Jeppesen, 2013; Moshari, 2013; Riege, 2005; Zurita et al., 2008; )

(b) Organisational barriers refer to firm or organisational barriers in terms of rewards, top management support, organisational structure, organisational culture, strategies, policies, and resistance to change (Amayah, 2013; Jain \& Jeppesen, 2013; Moshari, 2013; Nor, 2013; Othman et al., 2011; Riege, 2005)

(c) Technology barriers relate to the centralisation and integration of IT systems/processes, technical support, system maintenance, technology reluctance, and training (Othman et al., 2011; Riege, 2005)

These challenges or barriers (Riege, 2005) have affected KMS implementation in organisations and should be addressed and dealt with to ensure the success of collaborative KMS between MPSO. In addition, human factors are also important elements that need to be given attention. Motivation, incentives and promotion of knowledge-sharing culture should be assimilated within the organisation. Organisation management plays an important role in ensuring that knowledge and organisational culture are being practised within the organisation. Adopting modern technology in terms of technological 
infrastructure integrates and provides a suitable sharing platform accessible to all those in need of knowledge.

\section{Collaborative KMS within Public Sector Organisation}

CKMS is a discipline that allows KMS to cooperatively and mutually collaborate across the organisation's precincts to accomplish the organisation's desires and aspirations (Wu \& Gu, 2009). Through CKMS, organisations can collectively and systematically create, share, access and apply knowledge across organisations to achieve the organisation's objectives. CKMS also allows knowledge to flow throughout the organisation's network (Różewski et al., 2015). With CKMS, organisations are able to share and learn each other's expertise collaboratively in order to improve efficiency and productivity.

CKMS comprises a more holistic KM concept that encompasses both human and technology-oriented directions. MPSO can improve productivity through a consolidation and collaboration exercise, which will result in increased productivity, minimised redundancies, and improved efficiencies through centralised management and maintenance of shared resources.

\section{STUDY APPROACHES}

With comparison to previous studies, the related literature constructed on keywords is shown in Figure 3, including "governance", "knowledge management system", "social technical knowledge management system", "collaboration", "collaborative knowledge management system", "knowledge sharing" and "knowledge management governance". Journal articles for the literature review were sourced from renowned journal in knowledge management such as Knowledge Management Research \& Practice, Journal of Knowledge Management, Emerald, Science Direct, MIS Quarterly, and other academic databases.

Interview session with several academic experts in the field of knowledge management and governance were also acquired in identifying the possible components for collaborative KMS. Consultation process from the KM public sector expert team, as the practitioner and advisor for public sector KM implementation, has been used to refine the components obtained from readings and academic experts' opinion which provides critical, yet supportive feedback in fulfilling the requirements of KMS collaborations. 


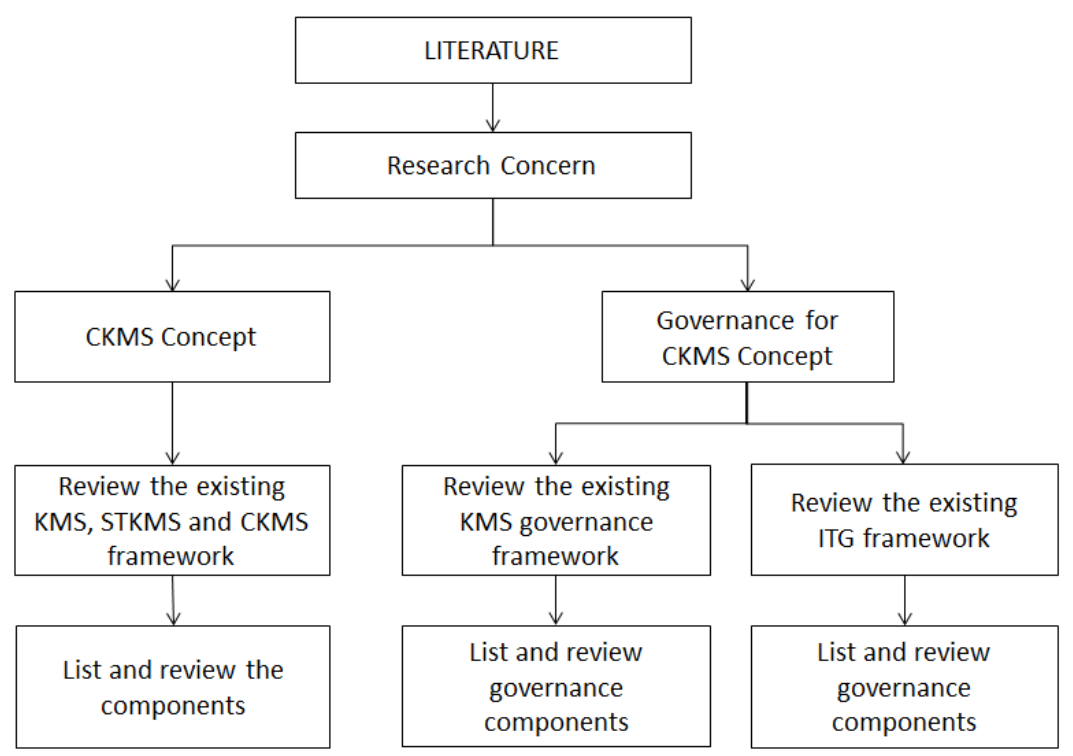

Figure 3. Related literature constructed on keywords.

\section{DISCUSSIONS}

Furthermore, in discussing the CKMS of governance and its components, we have divided it into several components as stated below:

\section{Governance Components for Collaborative KMS}

In previous studies, the elements of CKMS (Gallupe, 2001; McNabb, 2007; Meso \& Smith, 2000; Pan \& Scarbrough, 1999), KM governance components (Chourides, Longbottom, \& Murphy, 2003; Grundstein, 2006; Schroeder et al., 2012; Zyngier \& Mckay, 2006) and IT governance components (AbuMusa, 2009; Nor, 2013; Winniford et al., 2009) were reviewed, analysed and extracted. Expert views from several consultations with MPSO personnel and academic experts in governance and KM were analysed together with previous studies in identifying the governance components for CKMS. With reference to the literature review discussed in the previous section and expert view, the conceptual elements of collaborative KMS are identified and summarised as in Table 1. 


\section{Table 1}

Theoretical constructs of governance component for collaborative KMS

\begin{tabular}{|c|c|c|c|c|c|c|c|c|c|c|c|c|c|c|c|c|c|c|c|c|}
\hline \multirow{2}{*}{ 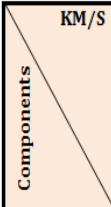 } & \multicolumn{5}{|c|}{ Socio-technical KM/S } & \multicolumn{4}{|c|}{ Collaborative KM/S } & \multicolumn{5}{|c|}{ KM/S Governance } & \multicolumn{3}{|c|}{ IT Governance } & \multicolumn{3}{|c|}{ Consultation } \\
\hline & 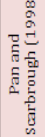 & 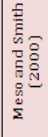 & 逹 & 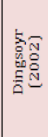 & 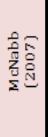 & 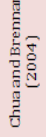 & 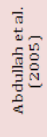 & 를 & 롱 & 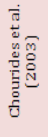 & 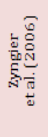 & 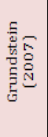 & 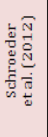 & 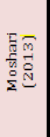 & 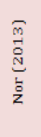 & 啇 & $\vec{E}$ & 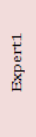 & 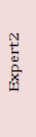 & $\begin{array}{l}\text { M } \\
\frac{0}{0} \\
\frac{1}{a}\end{array}$ \\
\hline People & & $\mathrm{x}$ & $\mathrm{x}$ & & & $\mathrm{x}$ & & & $\mathrm{x}$ & $\mathrm{x}$ & $\mathrm{x}$ & & $\mathrm{x}$ & $x$ & $\mathrm{x}$ & $x$ & & $\mathrm{x}$ & & $x$ \\
\hline $\begin{array}{l}\text { Knowledge } \\
\text { Management } \\
\text { Process }\end{array}$ & & $x$ & $\mathrm{X}$ & $x$ & $x$ & $\mathrm{x}$ & $x$ & $\mathrm{x}$ & $\mathrm{x}$ & $\mathrm{X}$ & $\mathrm{x}$ & $\mathrm{x}$ & $\mathrm{x}$ & $\mathrm{x}$ & & & $x$ & $\mathrm{x}$ & $\mathrm{X}$ & \\
\hline $\begin{array}{l}\text { Strategic } \\
\text { Management }\end{array}$ & & & & $x$ & & & $x$ & & & & $x$ & $x$ & $x$ & $x$ & $x$ & $x$ & $x$ & $x$ & & \\
\hline $\begin{array}{l}\text { Financial } \\
\text { Management }\end{array}$ & & & & & & & & & & & & & & $x$ & $x$ & $x$ & $x$ & $x$ & $x$ & $x$ \\
\hline $\begin{array}{l}\text { Organizational } \\
\text { Infrastructure }\end{array}$ & $\mathrm{x}$ & $\mathrm{x}$ & & & $x$ & $\mathrm{x}$ & $x$ & $\mathrm{x}$ & $\mathrm{x}$ & $\mathrm{x}$ & $\mathrm{x}$ & $\mathrm{x}$ & $\mathrm{x}$ & & $\mathrm{x}$ & $\mathrm{x}$ & $\mathrm{x}$ & $\mathrm{x}$ & $\mathrm{x}$ & $x$ \\
\hline $\begin{array}{l}\text { Technological } \\
\text { Infrastructure }\end{array}$ & $\mathrm{x}$ & $\mathrm{x}$ & $\mathrm{x}$ & $\mathrm{x}$ & $\mathrm{x}$ & $\mathrm{x}$ & $\mathrm{x}$ & $\mathrm{x}$ & $\mathrm{x}$ & $\mathrm{x}$ & $\mathrm{x}$ & $\mathrm{x}$ & $\mathrm{x}$ & $\mathrm{x}$ & $\mathrm{x}$ & & $\mathrm{x}$ & $\mathrm{x}$ & $\mathrm{x}$ & $x$ \\
\hline $\begin{array}{l}\text { Organizational } \\
\text { Learning }\end{array}$ & & & & & $\mathrm{x}$ & $\mathrm{X}$ & $\mathrm{x}$ & & & $\mathrm{x}$ & $\mathrm{x}$ & $\mathrm{x}$ & & $\mathrm{x}$ & & $\mathrm{x}$ & $\mathrm{x}$ & $\mathrm{x}$ & & \\
\hline $\begin{array}{l}\text { Knowledge } \\
\text { Culture }\end{array}$ & $\mathrm{x}$ & $\mathrm{x}$ & & & $\mathrm{x}$ & $\mathrm{x}$ & & $\mathrm{x}$ & $\mathrm{x}$ & $\mathrm{x}$ & $\mathrm{x}$ & $\mathrm{x}$ & & $\mathrm{x}$ & $\mathrm{x}$ & & & $\mathrm{x}$ & & \\
\hline $\begin{array}{l}\text { Collaborative } \\
\text { Environment }\end{array}$ & $x$ & $\mathrm{x}$ & $x$ & $\mathrm{x}$ & $\mathrm{x}$ & $\mathrm{x}$ & & $x$ & $x$ & X & $\mathrm{X}$ & $\mathrm{X}$ & $\mathrm{X}$ & $\mathrm{x}$ & & & & $\mathrm{x}$ & $\mathrm{x}$ & $\mathrm{x}$ \\
\hline
\end{tabular}

A comparison of the elements investigated, suggests that the elements identified has significant influence in the development of the governance component for CKMS (Table 1). Technological infrastructure, KM process and collaborative environment have been identified as the main elements in developing the governance component for CKMS. These components are also identified as the important elements in knowledge sharing culture (Amayah, 2013). The identification of these elements enables the research systematically compares and categorises the governance components for CKMS configurations.

From the study that has been conducted, as shown in Table 1, most of the elements $(70 \%)$ extracted are based on the KMS governance framework, and also $63 \%$ of the elements extracted were discussed during the expert consultation. Collaborative KMS contributes $60 \%$ of the elements, followed by IT governance with 57\%. Meanwhile, sosio-technical KMS contributed only $48 \%$ of the elements. Detail of the extracted elements is shown in Figure 4.

Figure 5 shows that the most important governance component for collaborative KMS is technological infrastructure with an overall importance of $94 \%$, followed by the organizational infrastructure, which is of $89 \%$ importance. 
This is followed by the collaborative environment that scores $83 \%$ importance and KM process with $78 \%$ importance. People and knowledge culture scores $61 \%$ importance respectively, while strategic management and organisational learning scores $44 \%$ importance respectively. The least important component is financial management, which is $33 \%$ importance.
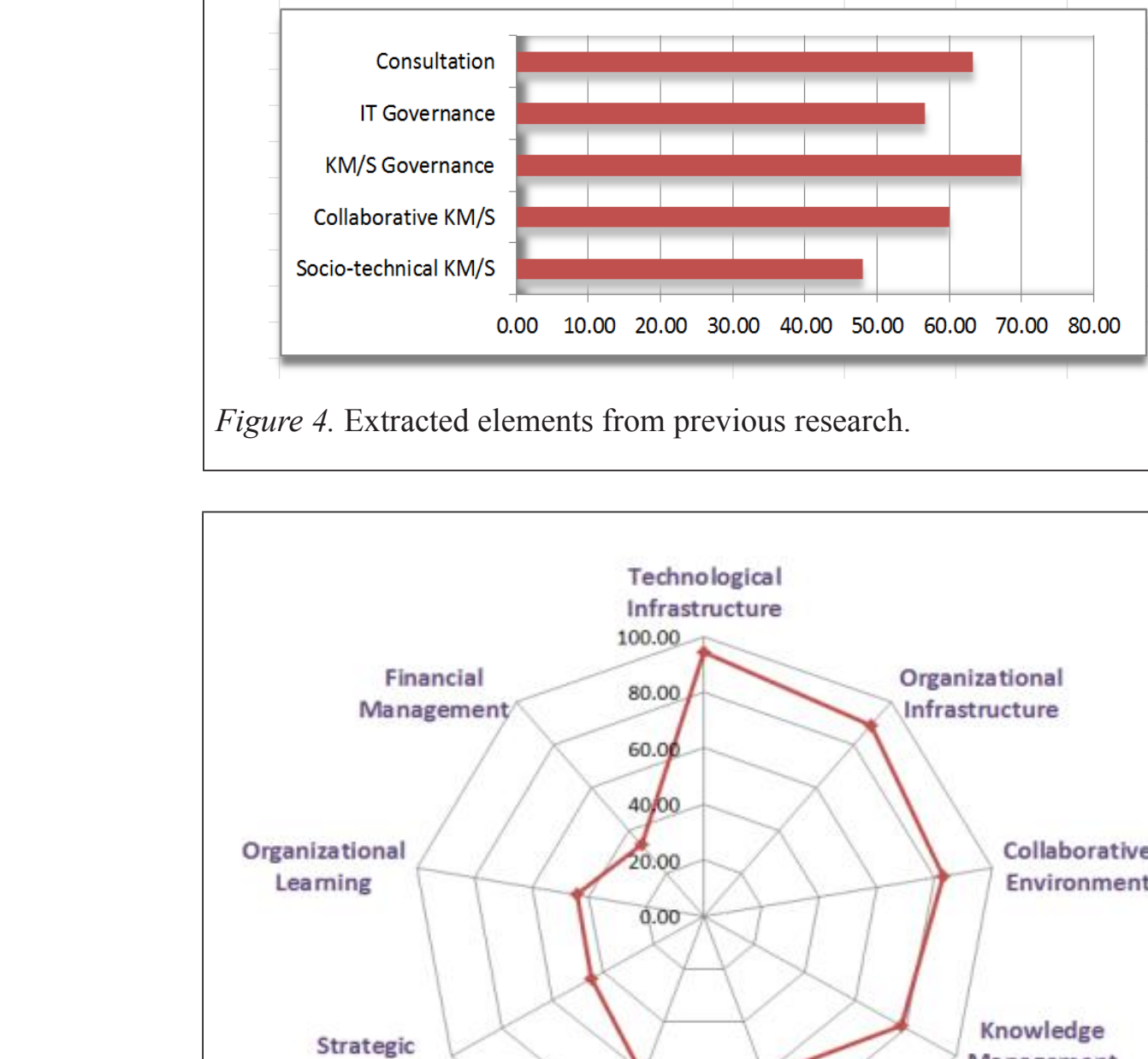

Figure 4. Extracted elements from previous research.

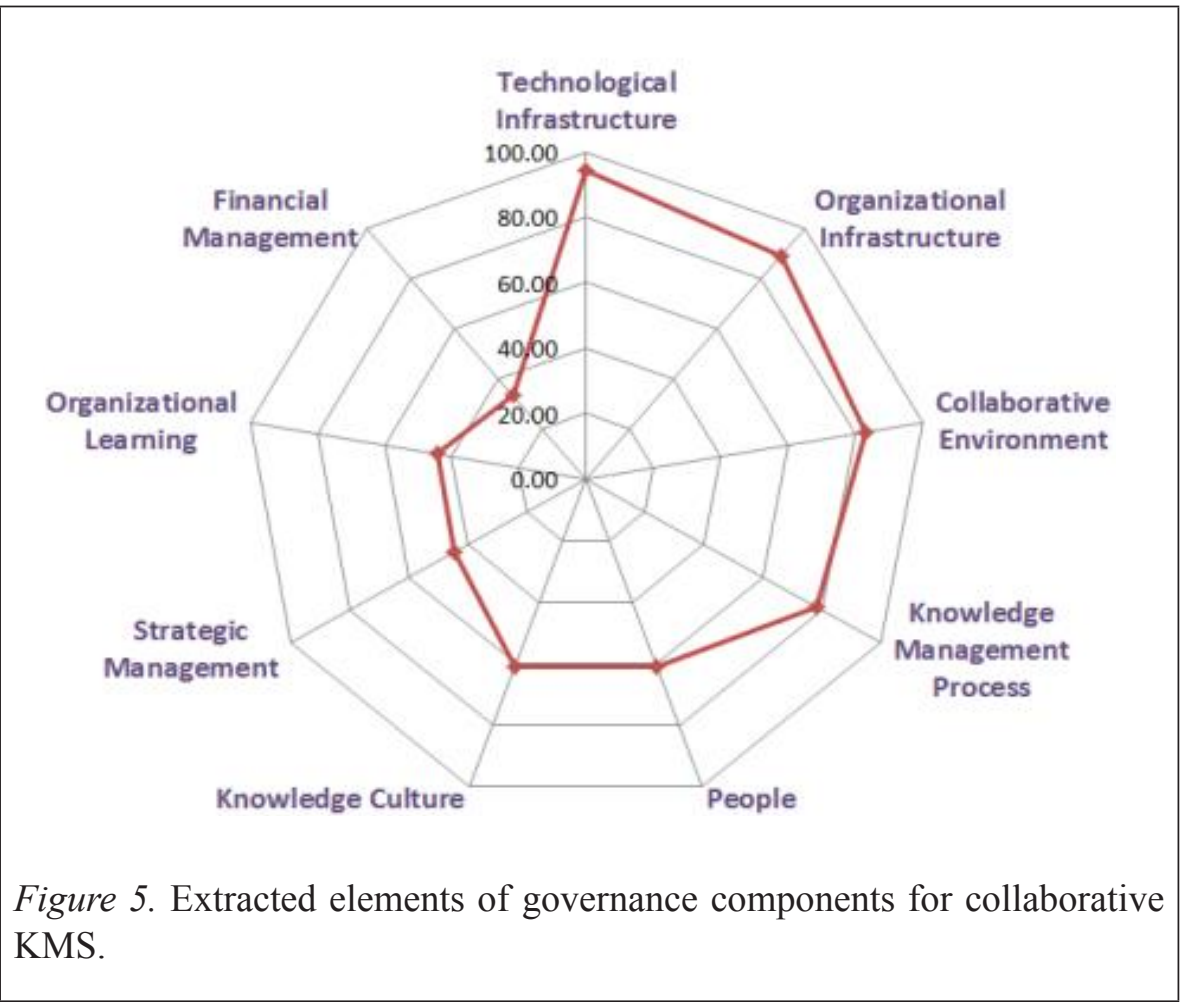


As shown in Figure 4 and Figure 5, the extracted and identified elements might be essential in developing governance of CKMS, which is divided into KMS layer, CKMS layer, supporting elements layer and KMS governance layer, as shown in Figure 6.

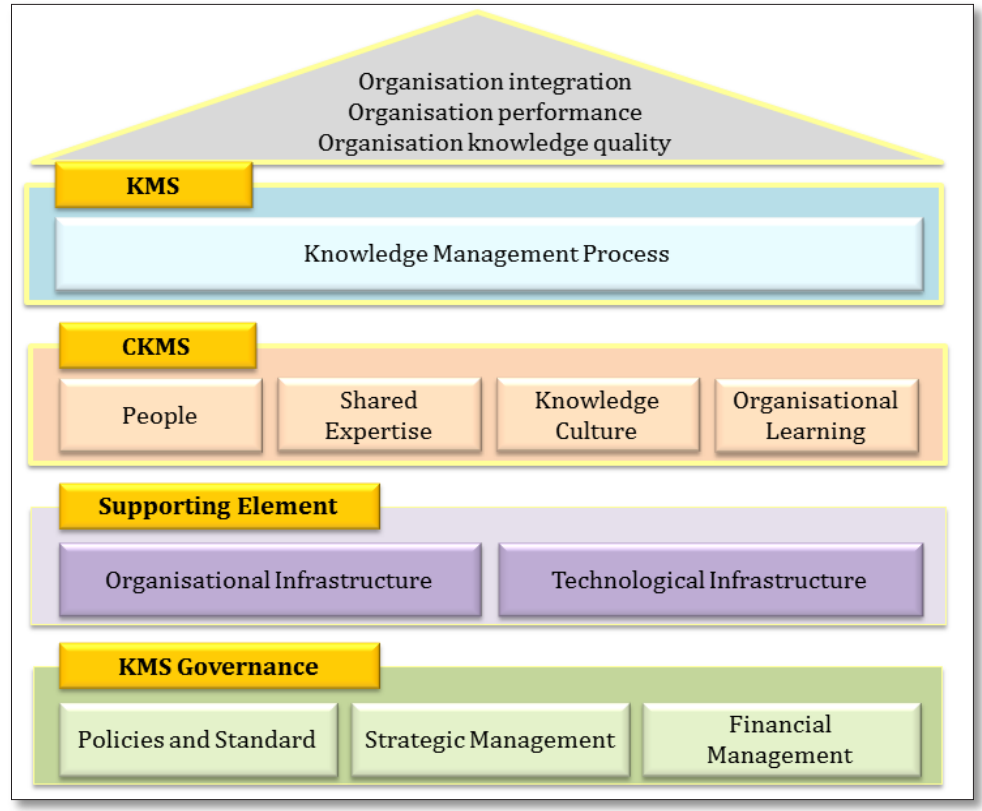

Figure 6. A Conceptual Model for CKMS Governance.

\section{A Conceptual Model for Governance of CKMS}

By adapting the Public Sector KM Framework, a conceptual model (Figure 6) of CKMS governance has been proposed to achieve:

(a) Organisation knowledge quality - knowledge content can be easily applied, accessed, disseminated and enhanced to improve the performance of a task and facilitate the decision-making process;

(b) Organisation integration - knowledge can be easily integrated and shared collectively and collaboratively;

(c) Organisation performance - knowledge can easily enhance organisational performance in terms of service quality and delivery.

The essential parameters of CKMS's governance components could be revealed analyzing critical success factors of knowledge management system. After a detailed analysis of the mentioned aspects, the conceptual model of a 
CKMS has been constructed (Figure 6). The main components of this model and their parameters have been discussed as illustrated in Table 2:

Table 2

Main Components and Parameters of Collaborative KMS

\begin{tabular}{|c|c|c|}
\hline $\begin{array}{l}\text { Elements of CKMS } \\
\text { components }\end{array}$ & Main parameters & Brief description \\
\hline $\begin{array}{l}\text { - Policy and Standard and } \\
\text { Organisational Strategy }\end{array}$ & $\begin{array}{l}\text { Policies and } \\
\text { Strategies }\end{array}$ & $\begin{array}{l}\text { This component to ensure that the } \\
\text { organization has a documented } \\
\text { policy and strategy that periodically } \\
\text { reviewed and practiced in the agency }\end{array}$ \\
\hline $\begin{array}{l}\text { - Strategic Management, KM } \\
\text { Strategy and COP }\end{array}$ & Leadership & $\begin{array}{l}\text { This component is to determine the } \\
\text { distribution of responsibility related } \\
\text { to knowledge management }\end{array}$ \\
\hline - Knowledge Culture & Incentives & $\begin{array}{l}\text { This component is to seek relevancy } \\
\text { of incentives provided by the } \\
\text { organizations }\end{array}$ \\
\hline $\begin{array}{l}\text { - Knowledge Culture and } \\
\text { Knowledge Process }\end{array}$ & $\begin{array}{l}\text { Knowledge } \\
\text { capture and } \\
\text { acquisition }\end{array}$ & $\begin{array}{l}\text { This component is to identify } \\
\text { knowledge aquisition }\end{array}$ \\
\hline - Organizational Learning & $\begin{array}{l}\text { Training and } \\
\text { Mentoring }\end{array}$ & $\begin{array}{l}\text { This component of the study the } \\
\text { training methods applied in the } \\
\text { organization }\end{array}$ \\
\hline $\begin{array}{l}\text { - Organizational Infrastructures, } \\
\text { Technological Infrastructure } \\
\text { and Collaborative } \\
\text { Environment }\end{array}$ & $\begin{array}{l}\text { Technology and } \\
\text { Communications }\end{array}$ & $\begin{array}{l}\text { This component is to identify of } \\
\text { knowledge sharing practices and the } \\
\text { use of ICT }\end{array}$ \\
\hline - Knowledge Culture & $\begin{array}{l}\text { Knowledge } \\
\text { Management } \\
\text { System Content }\end{array}$ & $\begin{array}{l}\text { This component to determine the } \\
\text { content of the knowledge management } \\
\text { systems agency }\end{array}$ \\
\hline - Financial Management & Financial Support & $\begin{array}{l}\text { This component to determine financial } \\
\text { support for KMS }\end{array}$ \\
\hline - Collaborative Environment & Collaboration & $\begin{array}{l}\text { This component to determine the } \\
\text { content of the knowledge management } \\
\text { systems agency }\end{array}$ \\
\hline
\end{tabular}

These parameters are considered to be the essential building blocks for CKMS's governance components. The results of analysis show that the $\mathrm{KM}$ process representing knowledge-related activities, the organisational infrastructure representing the organisation's social network and the 
technological infrastructure, which signifies ICT technology in facilitating the knowledge process, are among the important elements of CKMS.

As part of the organisational management, strategic leadership that acknowledges the value of $\mathrm{KM}$ is important as a governance element. Organisational learning and knowledge culture are processes that need to be embedded. The financial management, which is an important part of IT governance, has not been taken into consideration in the CKMS environment. The presented model can be used for the better understanding of governance for CKMS, and thus, can be implemented in the organisation.

\section{CONCLUSION}

A proper governance is required for the KMS of MPSO need to be consolidated and collaborated in order to ensure increased productivity, minimised redundancies and improved efficiencies through the centralised management and maintenance of shared resources.

The governance of the CKMS conceptual model includes two main subsystems: 1) the subsystem of knowledge management system governance, and 2) the subsystem of collaborative knowledge management system. Both subsystems are needed to ensure that governance of CKMS could be achieved.

This study contributes in identifying governance components of CKMS in order for coordinating and integrating KMS. The conceptual model was built from the nine components identified. The components were people, KM process, strategic management, financial management, organisational and technological infrastructure, organisational learning, knowledge culture and collaborative environment.

The conceptual model for the governance of CKMS developed in this study needs to be verified and validated in further research in order to gain better insights into the actual governance components of CKMS for Malaysian public sector organisations.

\section{REFERENCES}

Abdullah, R., \& Misran, E. K. (2010). Applying Agent Technology in Personal and Team Software Process Environment: The Usability Evaluation. Proceedings of Knowledge Management 5th International Conference 2010, 633-637. 
Abdullah, R., Sahibuddin, S., Alias, R. A., \& Selamat, M. H. (2006). Knowledge Management System Architecture For Organizational Learning With Collaborative Environment. International Journal of Computer Science and Network Security, 6(3), 237-246.

Abdullah, R., Sahibudin, S.,Alias, R. A., \& Selamat, M. H. (2005). Collaborative Knowledge Management Systems for Learning Organisations. Journal of Information \& Knowledge Management, 4(4), 237-245. doi:10.1142/ S0219649205001237

Abdullah, R., Shahabudin, S. bin, Alias, R. A., \& Selamat, M. H. (2007). Developing Knowledge Management System for Public Higher Learning in Collaborative Environment. International Journal of Computer Science and Network Security, 7(7), 11.

Abu-Musa, A. A. (2009). Exploring COBIT Processes for ITG in Saudi Organizations : An empirical Study. The International Journal of Digital Accounting Research, 9(April 2008), 99-126. doi:10.4192/15778517-v9

Alavi, M., \& Leidner, D. E. (1999). Knowledge Management Systems Issues, Challenges, And Benefits. Communications of AIS, 1(February), 1-37.

Ali, J. (2003). Mengurus Sumber Manusia. Dewan Bahasa dan Pustaka.

Amayah, A. T. (2013). Determinants of knowledge sharing in a public sector organization. Journal of Knowledge Management, 17(3), 454-471. doi:10.1108/JKM-11-2012-0369

BPA. (2012). Biro Pengaduan Awam: Laporan Tahunan 2012. Retrieved from www.pcb.gov.my

Brown, A. E., \& Grant, G. G. (2005). Framing the Frameworks: A Review of IT Governance Research. Communications of the Association for Information Systems (Volume, 15, 696-712.

Cao, Y., \& Xiang, Y. (2012). The impact of knowledge governance on knowledge sharing. Management Decision, 50(4), 591-610. doi:10.1108/00251741211220147 
Chourides, P., Longbottom, D., \& Murphy, W. (2003). Excellence in knowledge management: an empirical study to identify critical factors and performance measures. Measuring Business Excellence, 7(2), 2945. doi:10.1108/13683040310477977

Chua, A., \& Lam, W. (2005). Why KM Projects Fail: A Multi-Case Analysis. Journal of Knowledge Management, 9(3), 6-17. doi:10.1108/13673270510602737

Cormican,K., \& O’Sullivan, D. (2003). Acollaborative knowledgemanagement tool for product innovation management. International Journal of Technology Management, 26(1), 53. doi:10.1504/IJTM.2003.003144

Davenport, T. H. (1994). Saving IT's Soul Human-Centered Information Management. Harvard Business Review.

Davenport, T. H., \& Prusak, L. (1998). Working knowledge: How Organizations Manage What They Know. IEEE Engineering Management Review (Vol. 31). doi:10.1109/EMR.2003.1267012

Fazekas, M., \& Burns, T. (2012). Exploring the Complex Interaction Between Governance and Knowledge in Education. OECD Education Working Papers.

Gallupe, B. (2001). Knowledge management systems: surveying the landscape. International Journal of Management Reviews, 3(1), 61-77. doi:10.1111/1468-2370.00054

Gartner Group Inc. (1996). The Future of IT. In Symposium on the Future of Information Technology. doi:10.1017/CBO9781107415324.004

Grembergen, W. Van. (2004). Strategies for Information Technology Governance. Governance An International Journal Of Policy And Administration (Vol. 3). doi:10.4018/978-1-59140-140-7

Grembergen, W. Van, \& Haes, S. De. (2009). Enterprise Governance of Information Technology. Boston, MA: Springer US. doi:10.1007/9780-387-84882-2

Grundstein, M. (2006). Towards a Pattern of Reference to Elaborate KM Governance Principles: The MGKME Example. In ISOneWorld Conference 2006: Grand Challenges in Technology Management (pp. 1-11). 
Grundstein, M. (2008). Assessing Enterprise's Knowledge Management Maturity Level. International Journal of Knowledge and Learning, 4, 415-426.

Hernandez, M. (2003). Assessing Tacit Knowledge Transfer and Dimensions of a Learning Environment in Colombian Businesses. Advances in Developing Human Resources, 5. doi:10.1177/1523422303251370

IT Governance Institute. (2009). An Executive View of IT Governance.

Jain, A. K., \& Jeppesen, H. J. (2013). Knowledge management practices in a public sector organisation: the role of leaders' cognitive styles. Journal of Knowledge Management, 17(3), 347-362. doi:10.1108/JKM-112012-0358

MAMPU. (2011a). Information Architecture Blueprint. Public Sector ICT Blueprint, (January).

MAMPU. (2011b). Knowledge Management Blueprint. Public Sector ICT Blueprint.

McNabb, D. E. (2007). Knowledge Management in the Public Sector: A Blueprint for Innovation in Government. M.E.Sharpe Inc.

Meso, P., \& Smith, R. (2000). A resource-based view of organizational knowledge management systems. Journal of Knowledge Management, 4(3), 224-234. doi:10.1108/13673270010350020

Mohd Nor, M. Z., Selamat, M. H., Abdullah, R., \& Azmi Murad, M. A. (2009). Knowledge Sharing Interactions in Collaborative Software Maintenance Environment. In International Conference on Computer Technology and Development Knowledge (Vol. 2). doi:10.1109/ICCTD.2009.66

Moshari, J. (2013). Knowledge Management Issues in Malaysian Organizations: the Perceptions of Leaders. Journal of Knowledge Management, Economics and Information Technology, III(5), 1-13.

Ninth Malaysia Plan. (2006). Ninth Malaysia Plan - EPU.

Nonaka, I., \& Takeuchi, H. (1995). The Knowledge-Creating Company. How Japanese Companies Create the Dynamics of Innovation. Oxford University Press, New York. 
Nor, R. N. H. (2013). ICT Service Quality Measurement Framework For Malaysian Universities Context. Universiti Teknologi Malaysia.

Othman, M. F. I., Chan, T., Foo, E., Nelson, K., \& Timbrell, G. (2011). Barriers to Information Technology Governance Adoption: A Preliminary Empirical Investigation. In Proceedings of 15th International Business Information Management Association Conference, Cairo, Egypt (pp. 1771-1787).

Oyefolahan, I. O., Dominic, P. D. D., \& Karim, N. S. A. (2012). Towards an effective KMS usages: The role of socio-technical antecedents in the building of autonomous motivation to use. In 2012 International Conference on Computer and Information Science ICCIS 2012 (Vol. 1, pp. 89-93).

Pan, S. L., \& Scarbrough, H. (1999). Knowledge Management in Practice: An Exploratory Case Study. Technology Analysis \& Strategic Management, 11(3), 359-374. doi:10.1080/095373299107401

Peterson, R. (2004). Crafting Information Technology Governance. Information Systems Management, 32, 7-22. doi:10.1201/1079/44819. 32.6.20041201/85112.1

Riege, A. (2005). Three-dozen knowledge-sharing barriers managers must consider. Journal of Knowledge Management, 9(3), 18-35. doi:10.1108/13673270510602746

Różewski, P., Jankowski, J., Bródka, P., \& Michalski, R. (2015). Knowledge workers' collaborative learning behavior modeling in an organizational social network. Computers in Human Behavior, 51. doi:10.1016/j. chb.2014.12.014

Sajeva, S. (2011). Towards a Conceptual Knowledge Management System Based on Systems Thinking and Sociotechnical Thinking. International Journal of Sociotechnology and Knowledge Development, 3(3), 40-55. doi:10.4018/jskd.2011070103

Salleh, K. (2012). Knowledge Management in Public University : Empirical Relationships Between Learning Organization and Knowledge Management Process of Tacit Knowledge. In Knowledge Management International Conference (KMICe) 2012 (pp. 4-6). 
Sandhu, M. S., Jain, K. K., \& Ahmad, I. U. K. (2011). Knowledge sharing among public sector employees: evidence from Malaysia. International Journal of Public Sector Management, 24(3), 206-226. doi:10.1108/09513551111121347

Schroeder, A., Pauleen, D., \& Huff, S. (2012). KM governance: the mechanisms for guiding and controlling KM programs. Journal of Knowledge Management, 16(1), 3-21. doi:10.1108/13673271211198918

Schroeder, A., \& Pauleen, D. J. (2007). The emergence of KM Governance in a knowledge intensive research organisation. The Interdisciplinary Journal of Organizationory and Society, 1-16.

Tenth Malaysian Plan. (2011). Tenth Malaysia Plan - EPU.

Weill, P. (2004). Don't Just Lead,Govern How Top-Performing Firms Govern IT. MIS Quarterly Executive, 3(1), 17.

Weill, P., \& Ross, J. (2004). IT Governance: How Top Performers Manage IT Decision Rights for Superior Results. Harvard Bussiness School Pres.

Winniford, M., Conger, S., \&Erickson-Harris, L. (2009). Confusion in the Ranks: IT Service Management Practice and Terminology. Information Systems Management, 26(2), 153-163. doi:10.1080/10580530902797532

Wu, X., \& Gu, Y. (2009). Collaborative Knowledge Management System (CKMS) and Strategic Management. In 2009 International Joint Conference on Artificial (pp. 190-193). Ieee. doi:10.1109/ JCAI.2009.178

Zurita, G., Baloian, N., \& Baytelman, F. (2008). Mobile Collaborative Knowledge Management System. In 2008 12th International Conference on Computer Supported Cooperative Work in Design (pp. 588-593). IEEE. doi:10.1109/CSCWD.2008.4537044

Zyngier, S., \& Mckay, J. (2006). The Role of Knowledge Management Governance in the Implementation of Strategy . In Proceedings of the 39th Hawaii International Conference on System Sciences (Vol. 00, pp. 1-10).

Zyngier, S., \& Owen, J. (2013). Patterns of Knowledge Management leadership and delegation - supporting an agile organization. In 46th Hawaii International Conference on System Sci. 